(C) 1983. The Genetical Society of Great Britain

\title{
AN ABSENCE OF ENZYME VARIABILITY WITHIN TWO SPECIES OF TRIGONA (HYMENOPTERA)
}

\author{
ANNE E. WAGNER,* AND DAVID A. BRISCOE \\ School of Biological Sciences, Macquarie University, North Ryde, 2113, Australia \\ Received 12.vii.82
}

SUMMARY

\begin{abstract}
New South Wales and southern Queensland populations of two eusocial, stingless bees, (Trigona carbonaria and $T$. australis) were examined for enzyme variation at 20 gene loci. The high level of interspecific variation (60 per cent fixed gene difference) contrasted sharply with the absence of intraspecific variation over a $1400 \mathrm{~km}$ range. Factors which might underlie this effect such as reduced heterozygote advantage, inbreeding and low environmental variability within and between nests are discussed.
\end{abstract}

\section{INTRODUCTION}

Most natural populations possess a wealth of genetic polymorphism (Powell, 1975). Thus populations in which this variation is absent or at very low levels offer valuable contrasts in the study of evolution.

Of the hundreds of species whose level of genetic variation has been assessed by enzyme electrophoresis, twelve outcrossing species (Avise and Selander, 1972; Bonnell and Selander, 1974; Pamilo et al., 1978a ; Pamilo et al., 1978b; Selander et al., 1974; Snyder 1974; Webster et al., 1972) and three self fertilising species (Foltz et al., 1982) have shown no variation at all. Four of the outcrossing species reported as being monomorphic were vertebrates; a cave dwelling Astyanax fish, an Anolis lizard, a pocket gopher and an elephant seal. Interestingly, the remaining eight monomorphic, outcrossing species were members of the same order: Hymenoptera, the social insects. Furthermore, in other electrophoretic studies, many Hymenopteran species have displayed levels of genetic variation significantly lower than that of species from other orders. Explanations for these observations have included reduced heterozygote advantage, inbreeding, and the relative environmental stability conferred by the nest microhabitat. The low levels of electrophoretic variation displayed by Hymenopteran species pose genetic questions worthy of further investigation.

Trigona is a large Hymenopteran genus of eusocial stingless bees, not previously studied electrophoretically. Its fourteen subgenera have a tropical distribution and two subgenera and some twelve species are represented in Australia. One species in each Australian subgenus has penetrated as far as southern Queensland and New South Wales, where they compose a relatively isolated series of populations in this extreme southern limit of the genus. Here we report the levels of electrophoretic variation at 20 gene loci in these two species, Trigona carbonaria Smith and Trigona australis Friese.

* Present address: CSIRO, Division of Animal Production P.O. Box 239, Blacktown, NSW, 2148, Australia. 
FIG. 1. Distribution of all samples collected in New South Wales and Queensland.

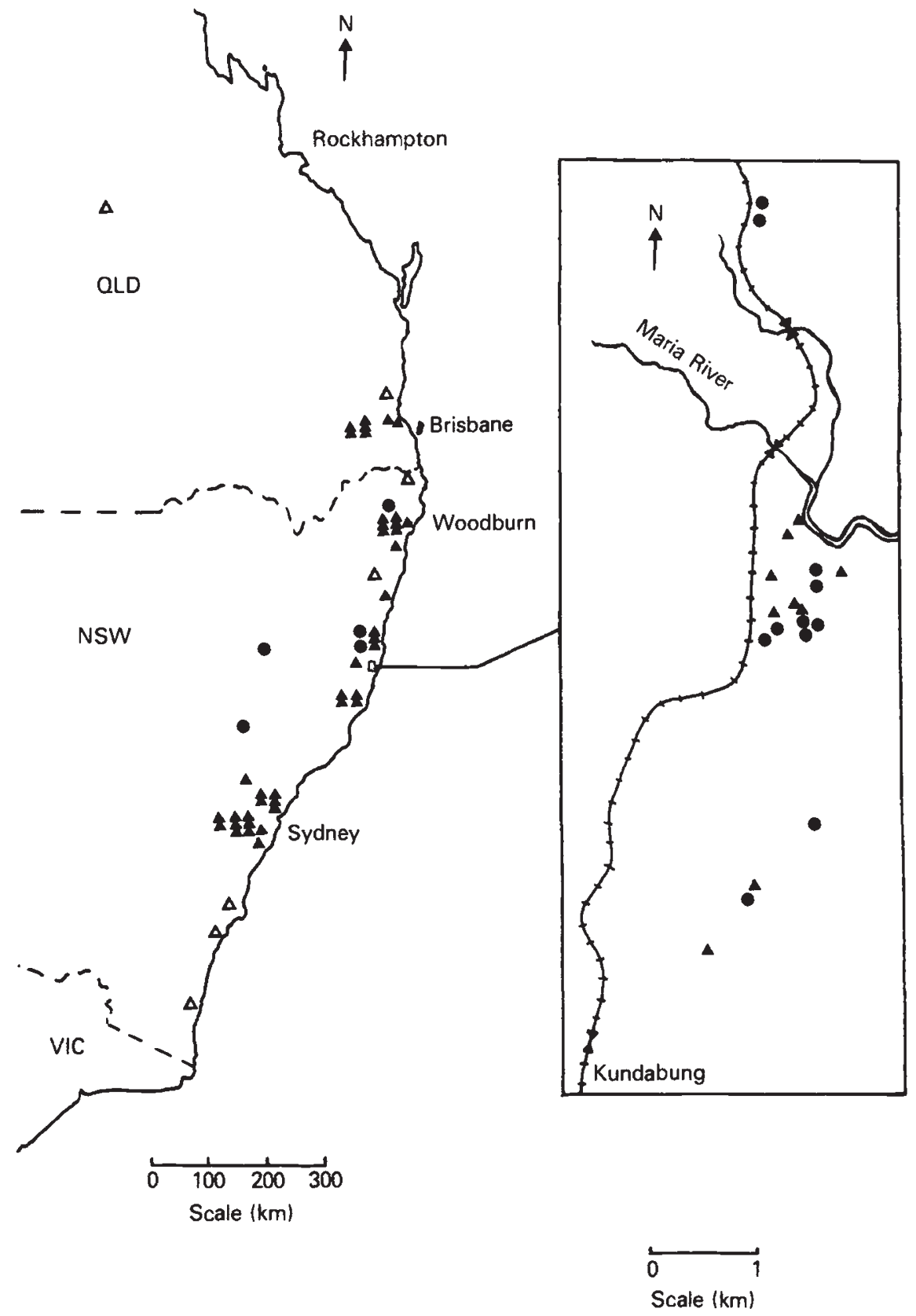

Key

$\Delta$ - sample from flowers or trees, $T$. carbonaria

$\Delta$ - nest sample, $T$. carbonaria

- nest sample, $T$. australis

Inset: samples collected from the sympatric population at Maria River State Forest, $10 \mathrm{~km}$ south of Kempsey, N.S.W. 


\section{Materials and Methods}

$T$. carbonaria and $T$. australis were sampled from 65 nests at the sites indicated in fig. 1 and table 1 . Bees were captured by holding a plastic bag over the nest entrance and then were immediately frozen in liquid nitrogen. Further samples were collected from bees which were foraging on flowers or collecting the sap exuded from turpentine trees (Syncarpia glomulifera (Sm.) Niedenzu) after a small wedge of bark and wood had been cut from the tree trunk. Trigona is strongly and specifically attracted to turpentine sap and may be collected for $24-48$ hours.

TABLE 1

Localities of the 65 nests and six samples in the study

\begin{tabular}{lccccc}
\hline \multicolumn{1}{c}{ Locality } & \multicolumn{2}{c}{ Co-ordinates } & \multicolumn{2}{c}{ Number analysed } \\
& $\mathrm{S}$ & $\mathrm{E}$ & T. carbonaria & T. australis \\
\hline Nests & & & & \\
Brisbane & $27^{\circ} 27^{\prime}$ & $153^{\circ} \circ 1^{\prime}$ & 2 & - \\
Gatton & $27^{\circ} 34^{\prime}$ & $152^{\circ} 17^{\prime}$ & 5 & - \\
Woodburn & $29^{\circ} 04^{\prime}$ & $153^{\circ} 21^{\prime}$ & 8 & - \\
Coffs Harbour & $30^{\circ} 18^{\prime}$ & $153^{\circ} 08^{\prime}$ & 1 & 2 \\
Allgomera Creek & $30^{\circ} 51^{\prime}$ & $152^{\circ} 47^{\prime}$ & 3 & 11 \\
Maria River & & & & \\
State Forest & $31^{\circ} 10^{\prime}$ & $152^{\circ} 51^{\prime}$ & 10 & - \\
Tamworth & $31^{\circ} 14^{\prime}$ & $151^{\circ} 01^{\prime}$ & - & - \\
Wauchope & $31^{\circ} 24^{\prime}$ & $152^{\circ} 45^{\prime}$ & 4 & - \\
Merriwa & $32^{\circ} 09^{\prime}$ & $150^{\circ} 21^{\prime}$ & - & - \\
Putty & $32^{\circ} 14^{\prime}$ & $150^{\circ} 18^{\prime}$ & 1 & - \\
Wyong Creek & $33^{\circ} 15^{\prime}$ & $151^{\circ} 20^{\prime}$ & 5 & - \\
Kurrajong & $33^{\circ} 33^{\prime}$ & $150^{\circ} 40^{\prime}$ & 10 & - \\
Samples & & & & - \\
Carnarvon Gorge & $24^{\circ} 55^{\prime}$ & $148^{\circ} 05^{\prime}$ & 1 & - \\
Nambour & $26^{\circ} 38^{\prime}$ & $152^{\circ} 58^{\prime}$ & 1 & - \\
Grafton & $29^{\circ} 41^{\prime}$ & $152^{\circ} 56^{\prime}$ & 1 & - \\
Tomerong & $35^{\circ} 03^{\prime}$ & $150^{\circ} 35^{\prime}$ & 1 & - \\
Ulladulla & $35^{\circ} 21^{\prime}$ & $150^{\circ} 29^{\prime}$ & 1 & - \\
Bega & $36^{\circ} 41^{\prime}$ & $149^{\circ} 51^{\prime}$ & 1 & - \\
\hline
\end{tabular}

Tissue extracts were prepared for electrophoresis by crushing individual bees in $10 \mu$ l of a lysing solution $(0.1 \mathrm{ml} 2$-mercapto-ethanol: $10 \mathrm{mg}$ NADP: $10 \mathrm{ml} \mathrm{H} \mathrm{H}_{2} \mathrm{O}$ ). The resulting exudate was applied to starch gel and run at $4^{\circ} \mathrm{C}$, under the conditions noted in table 2 . Histochemical staining for the twelve specific gene-enzyme systems analysed (table 2) were minor modifications of standard procedures (Harris and Hopkinson, 1976). Preliminary trials showed that whole organism extracts were as satisfactory as separate head, thorax or abdomen extracts and that frozen bees displayed comparable activity to freshly killed specimens.

\section{Results}

Twelve enzyme systems which, by comparison with other insects tentatively represent 20 gene loci, were successfully analysed by starch gel electrophoresis. The electrophoretic states (bands on the gel-table 3) 
TABLE 2

Enzyme systems analysed by electrophoresis*

\begin{tabular}{lll}
\hline Abbreviation & E.C. recommended name & E.C. number \\
\hline$\alpha$ GPDH & Glycerol-3-phosphate dehydrogenase (NAD ${ }^{+}$) & 1.1 .1 .8 \\
MDH & Malate dehydrogenase & 1.1 .1 .37 \\
ME & Malate dehydrogenase (oxaloacetate-decarboxylating) & 1.1 .1 .40 \\
& (NADP ${ }^{+}$) & \\
6PGD & Phosphogluconate dehydrogenase (decarboxylating) & 1.1 .1 .44 \\
G6PD & Glucose-6-phosphate dehydrogenase & 1.1 .1 .49 \\
SOD & Superoxide dismutase & 1.15 .1 .1 \\
HEX & Hexokinase & 2.7 .1 .1 \\
PGM & Phosphoglucomutase & 2.7 .5 .1 \\
ALD & Fructose-bisphosphate aldolase & 4.1 .2 .13 \\
FUM & Fumarate hydratase & 4.2 .1 .2 \\
PGI & Glucosephosphate isomerase & 5.3 .1 .9 \\
Esterases & Esterases & 3.1 \\
\hline
\end{tabular}

${ }^{*}$ Esterases were run for 2 hours at $5-8$ volts/ $\mathrm{cm}$ with esterase buffer (Electrode buffer $(p \mathrm{H} 8.2) \approx 12.0 \mathrm{~g}$ lithium hydroxide, $118.0 \mathrm{~g}$ boric acid in 11 distilled water (dilute $1: 10$ for use in tanks); gel buffer $\approx$ prepare a 3:5.2:200 part solution of electrode buffer: buffer A: distilled water, where buffer $\mathrm{A}(\mathrm{pH} 6.6)$ is $86.6 \mathrm{~g}$ Tris, $48.4 \mathrm{~g}$ citric acid in 11 distilled water).

The remaining enzymes were run for 3.5 hours at 10 volts $/ \mathrm{cm}$ with EDTA-Boric Acid Tris Buffer (Electrode buffer $\approx 15 \mathrm{~g}$ EDTA, $100 \mathrm{~g}$ boric acid, $151.5 \mathrm{~g}$ Tris (Sigma 7-9) in 2.51 distilled water (dilute $1: 5$ for use in tanks); gel buffer $\approx 1: 10$ dilution of electrode buffer).

TABLE 3

Electrophoretic mobilities for the twelve enzyme systems representing the 20 gene loci studied. Numbers refer to mobility in ascending order of anodal migration for each system. In the esterase group of enzymes, only the distinct, mostcathodal band was scorable

\begin{tabular}{lll}
\hline \multicolumn{1}{c}{$\begin{array}{c}\text { Enzyme system } \\
\text { abbreviation }\end{array}$} & \multicolumn{1}{c}{$T$ carbonaria } & \multicolumn{1}{c}{ T australis } \\
\hline SOD* & $1_{\mathrm{c}}, 2_{\mathrm{c}}$ & $3_{\mathrm{c}}, 4_{\mathrm{c}}$ \\
ME & 1 & 2 \\
6PGD & 1 & 2 \\
MDH $^{*}$ & $2_{\mathrm{c}}, 1,3$ & $1_{\mathrm{c}}, 2,4$ \\
ALD & 1 & 2 \\
HEX & $2,5,6$ & $1,2,3,4$ \\
FUM & 1 & 2 \\
Esterase & 1 & 2 \\
$\alpha$ GPDH & $1,2,3$ & $1,2,3$ \\
PGM & 1 & 1 \\
PGI & 1,2 & 1,2 \\
G6PD & 1 & 1 \\
\hline
\end{tabular}

* Bands labelled ' $c$ ' were cathodal bands, numbered in order of descending migration.

recorded, indicate that although there were considerable differences between $T$. australis and $T$. carbonaria, individual and nest variation within each species was absent. All proteins assayed within each Trigona species were monomorphic. 
Percentage fixed gene differences (percentage of loci fixed for alternative alleles in the compared groups), derived from the 20 loci scored, give a measure of the genetic differentiation between the groups. Within both species there were no fixed gene differences between nests. However, between $T$. carbonaria and $T$. australis, a 60 per cent fixed gene difference was recorded.

\section{DisCUSSION}

There is a striking contrast between the total lack of genetic variation within the New South Wales and southern Queensland Trigona species and the high level of divergence between them. The interspecific fixed gene difference is considerably greater than that typically observed between congeneric species (Avise, 1976) yet the intraspecific variation is much lower than normally observed (Powell, 1975). Perhaps the species separated early in their evolutionary history and attained their present state of divergence by independent evolution at an extremely gradual rate. Alternatively, they may have diverged in a sudden burst of evolution then stabilised to their current state.

More difficult to accommodate with theory is the mechanism maintaining the genetic uniformity within species over such an extensive range (16 populations over $1400 \mathrm{~km}$ in $T$. carbonaria; 5 populations over $400 \mathrm{~km}$ in T. australis). Hartl (1971) has shown that the expected level of variability under heterozygote advantage is lower for haplodiploid than for comparable diploid populations. Thus, a reduced extent of heterozygote advantage may contribute to the observed monomorphism.

Another selection model proposed to account for monomorphism in some Hymenopteran species is low nest environmental variability (Snyder, 1974; Pamilo et al., 1978a ; Pamilo et al., 1978b). Within Hymenopteran nests, the environmental fluctuations are likely to be far lower than the fluctuations in the gross external environment. For instance, Trigona spinipes continuously maintained a nest temperature of $35 \pm 1^{\circ} \mathrm{C}$ while ambient temperatures varied from 15 to $25^{\circ} \mathrm{C}$ (Zucchi and Sakagami, 1972). Within a series of nests maintaining similar microenvironments, the selective forces may be relatively uniform and could contribute to the lack of intraspecific variation observed. However, to maintain all the gene loci assayed in an unvarying homozygous state in all Trigona nests sampled, would require extreme selective forces. Thus, nest environmental stability is unlikely, by itself, to fully account for the lack of intraspecific variation.

Inbreeding within a small population has been used to explain the observed monomorphism in the elephant seal, Mirounga angustirostris (Bonnell and Selander, 1974), the lizard Anolis angusticeps (Webster et al., 1972) and the cave fish Astyanax mexicanus (Avise and Selander, 1972). Similarly, in social Hymenoptera, small effective population sizes arising from the social structure of the colonies could lead to inbreeding. In Trigona, for example, probably only three or four reproductives, out of a nest of thousands of bees contribute genetically to the next generation. Thus the effective population size is very low and a high level of inbreeding must occur unless specific outbreeding mechanisms have evolved. As the frequencies of deleterious recessive alleles in the haplodiploid Hymenoptera should be low, since they are constantly eliminated in the haploid 
males, close inbreeding is possible without a severe reduction in viability (Pamilo et al., 1978b).

Inbreeding, however, does not satisfactorily explain the Trigona data as inbred populations tend to display local fixed gene differences and these were not found. Theoretical studies in population genetics indicate that very low levels of migration (in the order of one individual exchanging between populations per generation) are sufficient to maintain uniformity between adjacent populations (Kimura and Ohta, 1971). Trigona live in dense clusters of colonies and the drones swarm. Thus, migration between neighbouring clusters of colonies may be possible and a fine balance between migration and inbreeding could underlie the phenomenon observed. The stability of such a fine balance is, however, questionable.

Alternatively, all nests of a particular species sampled in this study may be derived from a single ancestral nest and insufficient time may have elapsed since this founding event for new electrophoretic variants to have arisen by mutation and become fixed in local populations. The plausibility of this model cannot be assessed until the vagility of Trigona reproductive castes is known.

Acknowledgements. We are indebted to the many apiarists and timbercutters who provided samples of bees. We are also grateful to Dr R. Crozier (UNSW) for his help with insect electrophoresis techniques and to Mr J. Stevens for technical assistance. Drs J. Murray, R. Frankham and I. Franklin provided valuable advice on the preparation of the manuscript and the referees' comments were appreciated. Finally, AEW especially thanks Mr Leslie Dollin for his dedicated assistance in the field and for sharing the joys of native bees.

\section{REFERENCES}

AVISE, J. C. 1976. Genetic differentiation during speciation. In Ayala, F. J. (ed.) Molecular Evolution, Sinauer Associates, Inc., Massachusetts, pp. 106-122.

AVISE, J. C. AND SELANDER, R. K. 1972. Evolutionary genetics of cave-dwelling fishes of the genus Astyanax. Evolution, 26, 1-19.

BONNELL, M. L. AND SELANDER, R. K. 1974. Elephant seals: genetic variation and near extinction. Science, 184, 908-909.

FOLTZ, D. W., OCHMAN, H., JONES, J. S., EVANGELISTI, S. M. AND SELANDER, R. K. 1982. Genetic population structure and breeding systems in arionid slugs (Mollusca: Pulmonata). Biological Journal of the Linnean Society, 17, 225-241.

HARRIS, H. AND HOPKINSON. D. A. 1976. Handbook of Enzyme Electrophoresis in Human Genetics. North-Holland Pub. Co., Amsterdam.

HARTL, D. L. 1971. Some aspects of natural selection in arrhenotokous populations. American Zoologist, 11, 309-325.

KIMURA, M. AND OHTA, T. 1971. Theoretical Aspects of Population Genetics. Princeton University Press, Princeton.

PAMILO, P., ROSENGREN, R., VEPSÄLÄINEN, K., VARVIO-AHO, S. AND PISARSKI, B. 1978a. Population genetics of Formica ants: 1. Patterns of enzyme gene variation. Hereditas, $89,233-248$.

PAMILO, P., VARVIO-AHO, S. AND PEKKARINEN, A. 1978b. Low enzyme gene variability in Hymenoptera as a consequence of haplodiploidy. Hereditas, 88, 93-99.

POWELL, J. R. 1975. Protein variation in natural populations of animals. Evolutionary Biology, $8,71-119$.

SELANDER, R. K., KAUFMAN, D. W., BAKER, R. J. AND WILLIAMS, S. L. 1974. Genic and chromosomal differentiation in pocket gophers of the Geomys bursarius group. Evolution, $28,557-564$.

SNYDER, T. P. 1974. Lack of allozymic variability in three bee species. Evolution, 28, 687-698. 
WEBSTER. T. P., SELANDER, R. K. AND YANG, S. Y. 1972. Genetic variability and similarity in the Anolis lizards of Bimini. Evolution, 26, 523-535.

ZUCCHI, R. AND SAKAGAMI, S. F. 1972. Thermoregulatory capacity of Trigona spinipes and some other species of stingless bees. In Homenagem à Warwick E. Kerr, Faculade de Filosofia, Ciências e Letras, Rio Claro, pp. 301-309. 